Please do not remove this page

RMIT

UNIVERSITY

\title{
What do we really know about the outcomes of Australian international education? A critical review and prospectus for future research
}

Cuthbert, Denise; Smith, Wendy; Boey, Janice

https://researchrepository.rmit.edu.au/esploro/outputs/9921858229601341/filesAndLinks?institution=61RMIT_INST\&index=null

Cuthbert, D., Smith, W., \& Boey, J. (2008). What do we really know about the outcomes of Australian international education? A critical review and prospectus for future research. Journal of Studies in International Education, 12(3), 255-275. https://doi.org/10.1177/1028315307308134

Document Version: Accepted Manuscript

Published Version: https://doi.org/10.1177/1028315307308134

Repository homepage: https://researchrepository.rmit.edu.au

(c) 2008 SAGE Publications

Downloaded On 2023/04/26 21:56:59 +1000

Please do not remove this page 
Thank you for downloading this document from the RMIT Research Repository.

The RMIT Research Repository is an open access database showcasing the research outputs of RMIT University researchers.

RMIT Research Repository: http://researchbank.rmit.edu.au/

\section{Citation:}

Cuthbert, D, Smith, W and Boey, J 2008, 'What do we really know about the outcomes of Australian international education? A critical review and prospectus for future research', Journal of Studies in International Education, vol. 12, no. 3, pp. 255-275.

See this record in the RMIT Research Repository at:

http://researchbank.rmit.edu.au/view/rmit:15847

Version: Accepted Manuscript

Copyright Statement: (c) 2008 SAGE Publications

Link to Published Version:

http://dx.doi.org/10.1177/1028315307308134 


\title{
What Do We Really Know About the Outcomes of Australian
}

International Education?

\section{A Critical Review and Prospectus for Future Research \\ Denise Cuthbert, Wendy Smith \& Janice Boey \\ Contact: denise.cuthbert@rmit.edu.au}

\begin{abstract}
Australia has been a significant provider of international education in the Asia-Pacific region since 1950 with the inception of the Colombo Plan. Thus, graduates from these early days would by now be mature professionals in a variety of fields, with several decades of professional and academic attainment enabled by their Australian education. Yet we actually know very little about the outcomes over time of the graduates of Australian international higher education. In this article, the authors review the scholarly literature on the outcomes of international education, education provided by Australian universities and by others, and critically consider some of the limitations of the data and the methodologies that have dominated this area of research. Finally, in an effort to put current debates on international education on a more informed basis, the authors outline a prospectus for future research to redress some of these shortcomings.
\end{abstract}

Keywords: Australian international education; Colombo Plan; higher education and development; international graduate outcomes

\section{Full text}

Tertiary education is a key international business for Australia:

1. It is one of Australia's top five exports and, with an average annual growth rate of $11 \%$ in the past decade, it is one of the fastest growing industries within that group (that includes coal, iron ore, and gold); growth in educational service exports also exceeds the annual rate of growth of total service export. 
2. In 2004, educational exports earned more than AU\$6 billion ( $€ € 3.5$ billion, US\$ $\$ 4.7$ billion). This compares with around AU\$2 billion (€€1.1 billion, US\$1.5 billion) in 1994.

3. In 2005, the number of international students enrolled in Australian higher education institutions exceeded 160,000, and in 2006 this figure reached 172,297, compared with around 35,000 in 1994 (figures from Department of Foreign Affairs and Trade [DFAT], 2005; and Australian Education International, Department of Education Science and Training [AEI], 2006).

Australia has been providing international education for at least 55 years. International education commenced in a systematic way with the Colombo Plan in 1950 . The plan took its name from the location of a meeting of British Commonwealth Foreign Ministers in Colombo in January 1950 (Lowe \& Oakman, 2004, p. xvii) whose agenda was to formulate mechanisms for regional cooperation. Under the Colombo Plan, Australia provided scholarships and fellowships for students from a range of countries in the region and beyond to study in Australia (Auletta, 2000; Lowe \& Oakman, 2004; Oakman, 2004). Through the Colombo Plan and successor schemes, most recently the Australian Development Scholarships (ADS) provided by AusAID (1999a, 1999b, 2000, 2001, 2003) the Australian government's international aid agency that operates within the DFAT, Australia became a leading higher education provider in the Asia-Pacific region. As is generally acknowledged, it was through the provision of "education as aid" to Colombo Plan fellows that many Australian institutions commenced the processes of internationalisation that have developed apace over the past 20 years (Auletta, 2000; Oakman, 2004). During this period of intensive internationalisation, the focus of Australian higher education has shifted from "education as aid" to education provided on a commercial basis.

Although the successor of the Colombo Plan Fellowship Scheme, AusAID's ADS supports around 1,000 students from developing countries to commence studies in Australia each year (AusAID, 2003), these AusAID fellows now take their place alongside many more privately funded international students. As the figures cited above reveal, with total international enrolments in Australian higher education institutions now exceeding 170,000 (AEI, 2006) as compared with 1,000 commencing AusAID fellows in the same year, the extent to which the paradigm has shifted from aid to commerce can be gauged. 
The shift in Australian international higher education from education as aid to education as trade is usefully documented by several scholars (Back, Davies, \& Olsen, 1996; Smart \& Ang, 1993, 1996). The period between 1950 and 1972 saw steady numbers of sponsored students from developing countries study in a range of courses in Australian universities. With the abolition of university tuition fees by the Labor government of Gough Whitlam, the early 1970s witnessed increasing numbers of foreign students taking advantage of this new regime. In 1986, an Overseas Student Charge (OSC) was introduced by which private, non-government-sponsored overseas students were required to pay one third of the actual cost of their tuition with the remainder seen to be a component of the government foreign aid budget, indicating the persistence of the aid paradigm in this sector even as some cost-recovery measures were being instituted. A far more dramatic change was initiated with the implementation of recommendations of the Jackson report into Australia's international aid programs (Jackson, 1984) that called for an end to the aid approach in the provision of international higher education, and to place Australian higher education on a more "competitive" footing (Smart \& Ang, 1996). Influencing policy direction in this period was Australia's relatively weak and deteriorating position in the balance of international trade, for which "trade" in international education was posited as one remedy.

The Jackson report recommended overseas students who were not accommodated within the quota for subsidised students to be enrolled without numerical limits, as long as they met the institution's entry requirements and paid the full cost of their courses. The shift from educational aid to educational trade had thus commenced in earnest (Back et al., 1996). Despite expressions of outrage from Australian academics, foreign students, and their governments at this significant shift in the provision of Australian international education, most universities saw little alternative but to engage in the pursuit of revenue through competitive marketing and student recruitment programs that resulted in a spectacular growth of international student enrolments (Smart \& Ang, 1996). This led, in some institutions, to the overemphasis on foreign students as a source of "export income" and the short-sighted nature of some Australian advertising and recruitment overseas that, arguably, have damaged the reputation of some universities internationally. As Smart and Ang (1993) pointed out, in many Asian cultures, the trade-based view of education as just another marketable commodity runs counter to traditional views of the role and status of education. Aware of some resistance to, and distaste for, the rhetoric of "education as 
trade," the federal government moved in the early 1990s to a different articulation of policy on international education, deemphasising the "trade" dimension and emphasising "internationalisation," a process by which international students were to be but one component of a truly internationalised sector characterised by international research and teaching links, internationalised curriculum from which local students would also benefit, and staff exchanges. The degree to which the rubric of internationalisation has quelled criticism from within and outside the sector is questionable, as Philip Altbach wrote in 2000: "Some universities have been all too willing to involve themselves in commercial activities and to compromise their traditional roles. For example ... Monash University, a well-known Australian institution, is establishing profit-making branches overseas" (pp. 5-6).

The education of international students within Australian higher education has been shaped and transformed by these policy shifts from aid, to trade, to internationalisation, with students studying in Australia or in Australian institutions on a variety of terms: privately funded, funded by the Australian government, by their home governments, or by other agencies. Furthermore, international students gain access to Australian higher education and select courses of study based on an array of considerations ranging from academic merit alone, capacity to pay the fees, and to fulfil their home countries' economic development objectives by securing a qualification that will yield maximum long-term income earning potential. Although these factors remain variable, a question that applies to all Australian international graduates relates to the value of their education. Remarkably, we have very little information to assist in answering this question. One useful strategy in guiding the Australian higher education system through its rapid transition to large scale internationalisation and in providing an account of the quality of the education provided by the sector, irrespective of how it is funded, would be to examine the medium- to long-term career (and other) outcomes for international students educated within the Australian higher education system. Within an "education-as-aid" paradigm, this inquiry would go some way to assessing the efficacy of educational aid in terms of capacity building in the graduates' countries of origin. Quite apart from considerations of education as aid, such data could begin to answer questions about the quality and relevance of Australian education and its value, over time. With respect to wider contexts, beyond education and aid, there is a range of questions for which we need answers and for which, we contend, more focused research into Australian-educated graduates in the Asia-Pacific region may 
shed some light. For example, to what extent have Australian-educated graduates had an impact on the processes of democratisation and industrialisation in the region? Do concentrations of Australian-educated graduates in certain fields or certain organisations predispose these organisations to collaborations with Australian industry and business? And, abstracting from these considerations, is it possible that learning more about the medium- to long-term careers and activities of Australian-educated graduates may tell us something about the impact of Australian education on the processes of transnationalism and globalisation in the region, and about regional security and integration?

\section{WHAT DOES THE LITERATURE TELL US ABOUT GRADUATE OUTCOMES?}

As Grant Harman (2005) argued in his detailed survey of literature of the field published since 1990, the internationalisation of Australian higher education has been accompanied by significant levels of scholarship and research by Australian educational researchers and others who have posed questions-often difficult and searching ones-over a wide range of issues raised by rapid increases in the levels of international student enrolments in Australian universities and the equally rapid development of a range of internationalising activities that have seen Australian educational programs move "off shore" in a variety of formations: These include twinning and joint badging programs and the establishment of overseas campuses with fully accredited status as private universities within the country concerned. Harman usefully classified the research literature on internationalisation into several broad categories: literature that theorises and distinguishes between internationalisation and globalisation; literature that traces the process of internationalisation of Australian higher education; literature that analyses the Australian policy and regulatory frameworks for international education; literature that examines the export of education services; literature that examines international students and attempts some understanding/evaluation of the international student experience within the classroom and outside; and "other" topics that include literature that looks at the impact of internationalisation on curricula and pedagogy in Australian universities and on the research agenda of individual universities, where the making of international research links has become an increasing priority.

However, when this "substantial and impressive" (Harman, 2005, p. 132) literature is interrogated for answers to questions about the medium- to long-term outcomes of the 
international graduates of Australian education, it is virtually silent: "Comparatively little is available in the way of longer-term follow studies of international students' education in Australian universities" (Harman, 2005, p. 132). Harman's assessment of research on international graduate outcomes is echoed by Pam Nilan (2005) in her report of a study of a group of AusAID-funded Indonesian graduates: "Few independent evaluations of [the] success [of the AusAID ADS program] in relations to its key objectives have taken place" ( $p$. 164). International graduates on fellowships funded by AusAID or its predecessor, the Colombo Plan, though an increasingly small proportion of the overall international student population within Australian universities, remain equally under-researched with respect to the outcomes of their Australian higher education through an examination of their subsequent carers and their individual contributions to national development. This is despite the long history of Australia's involvement in "education-as-aid" programs and the fact that throughout the Asia-Pacific region, and elsewhere, there are Australian-educated graduates who are now mature professionals in a variety of fields. The lack of data on the medium- to long-term outcomes of AusAID graduates is a recurring theme in the 1999 report into the management of the ADS scheme by the Australian National Audit Office (ANAO; 1999):

AusAID does not have performance indicators to measure the outcomes of ADS in terms of students contributing to their country's development. The ANAO recognises that the measurement of ADS outcomes is difficult because of the time lags in returning students making contributions to their country's development, and the difficulty of relating individual efforts to broader economic and other developmental outcomes. (para. 21)

As assessed by the ANAO, the lack of data on graduate outcomes is an impediment to not only the full accountability of the ADS program but also to effective "future planning" (ANAO, 1999, para. 22):

The scholarship assistance guiding principles would be improved by indicating the contribution of scholarship assistance to the broader goal for Australian education and training assistance, its integration into aid programs for each country and its roles in helping to meet human resource development needs of those countries. (ANAO, 1999, para. 16)

In this respect, AusAID should not be singled out as particularly deficient: AusAID's lack of data on the outcomes of its graduates over time is a problem shared by the Australian higher education sector as a whole-particularly with respect to international 
students (Harman, 2005) and also with respect to the outcomes from higher degrees, including doctorates, for local and international students (Trembath, 1999). Furthermore, with respect to international students beyond the Australian context, generally and within "education-as-aid" contexts, the state of knowledge on the medium- to long-term outcomes of graduates globally is not much better. Within the development context, the World Bank, for example, a long-time provider of fellowships to students from developing countries in its own right and in conjunction with bodies such as the Japan Bank, recognises the limitations of research, including its own, in the area of graduate outcomes (World Bank, 2004a). It should be recognised, however, that, as is clearly demonstrated in the Graduate Careers Council of Australia scoping study on the longer term outcomes of Australian PhDs (Trembath, 1999), research that tracks graduates of any kind through the medium- to longterm development of their careers is very rare. In this respect, the work of Maresi Nerad and Joseph Cerny (1999), who have undertaken 5- and 10-year studies of doctoral graduates in the United States in a range of disciplines, stands out as one of the few pieces of research of this kind.

\section{WHY HAS THIS AREA BEEN UNDER-RESEARCHED?}

We should not be too surprised at the lack of research in this area. In the Australian context, with a few program-specific exceptions and country-specific studies (for studies of Indonesian students' experiences with some focus on outcomes, see Cannon 1999, 2000; Daroesman \& Daroesman, 1992; Nilan, 2002, 2005), graduate outcomes research generally remains limited to the annual "four month out" snapshot prepared by the Graduate Careers Council of Australia (refer to the Graduate Careers Council of Australia Web site, http://www.graduatecareers.com.au, for the annual publication, Graduate Destination Survey). The lack of medium- to long-term data that tells us more about graduate outcomes than labour market first destinations is a sectoral-wide problem, elaborated on in some detail in a scoping study prepared for the Australian Research Council by the Graduate Careers Council of Australia in 1999 that outlines a proposal for research into the medium to long-term outcomes of Australian doctoral graduates (Trembath, 1999). Practically and methodologically (which, of course, translates to financially), the problems involved in mounting this kind of research are considerable. To gain data from midcareer graduates involves tracking exercises that are costly, and costs are compounded when the 
international dimension is added. This challenge is closely related to challenges faced by universities in maintaining contact with alumni, particularly international alumni (Gairing, 2001; Visser, 2001).

Placing the challenges and costs of tracking graduates to the side, it must also be said that a further impediment to research of this kind remains the theoretical and methodological fuzziness around the specific (and demonstrable) connections between higher education and its often-asserted, but rarely established, benefits to the individual and the community. The challenges are recognised by the ANAO in its report on the management of the ADS scheme by AusAID as logistical, "because of the time lags in returning students making contributions to their country's development" (ANAO, 1999, para. 21), and methodological, as in "the difficulty of relating individual efforts to broader economic and other developmental outcomes" (ANAO, 1999, para. 21).

\section{EDUCATIONAL OUTCOMES: SOME THEORETICAL CONSIDERATIONS}

Although there is insufficient scope in this article for an exhaustive review of the theoretical literature, it is readily apparent that there is some lack of clarity in the existing work that attempts to assess the outcomes of education, whether using economic modelling methodologies, sociological approaches, or undertaken within the "education-as-aid for development" paradigm. For example, economists have argued the economic value of education by naming the United States and Japan as examples of societies that demonstrated great progress in education that accompanied and enabled rapid economic growth. It is argued that in the United States the economic value of education that was measured as an investment in human capital was responsible for much of the economic growth there during the 1920s and the 1950s (Shamsul Huq, 1965). Similarly, Japan's unprecedented economic development beginning in the Meiji period from 1868 was distinguished by a skilled and adaptive workforce, with many graduates receiving their education in Western countries to enable the rapid industrialisation that took Japan from the feudal, preindustrial isolation of the Tokugawa shogunate into the modern era in a matter of decades (Morris \& Sweeting, 1995; Shamsul Huq, 1965).

Human capital theories recognise the relationship between the quality of the labour force and various indicators for economic growth. However, attempts to provide empirical evidence to support the links between education and economic growth have not been 
entirely persuasive, and many are now outdated. For example, macro-level studies that compare various educational indicators and growth rates, in an attempt to provide measures of the return on the investment in education, have been less than clear-cut; and over time the significance of education as an important contributor to economic growth has been substantially reduced (Harris \& Jarrett, 1990). Other critics have suggested that neither time series nor cross-country studies lend much support to the hypotheses of direct links between education and economic growth (Maglen, 1990; Tapingkae, 1976).

The picture that emerges from micro-level research is not much clearer. This is notwithstanding the prevalence of generalised comments about the value of education as a universal public good, as in the following, one of many axiomatic statements made by the World Bank (2002):

Tertiary education can offer better opportunities and life chances for students from low income and other minority groups, thereby increasing their employability, income prospects and social mobility and decreasing income inequality. At the same time, the norms, values, ethics and knowledge that tertiary education can impart to students contribute to the social capital necessary to construct healthy civil societies and socially cohesive cultures, as well as to achieve good governance and democratic political systems [italics added]. (p. 5)

It is probably accurate to say that most, if not all, of us engaged in higher education believe the claims to its transformative powers at the level of the individual and society. It appears, though, that this is difficult to establish. Reading back from data on economic activity to data on levels of education, correlations appear. However, reading the other way around, from data on levels of education to levels of economic activity, the links - or rather, direct and demonstrable links-are less readily established. Another way of expressing the problem is that the research done to date appears unable persuasively to establish the connection between the private benefits of education for individual graduates and the public good. Hence the task of measuring returns from the investment made in education, beyond the level of the individual, remains a challenge. It is generally recognised that education provides individuals with bodies of knowledge and skills that can alter the quality of factor inputs, especially those of labour and management, increase the rate of adoption of new technology, and increase adaptability in the changing workforce that consequently will lead to labour productivity increase that will then bring returns on the 
investment made in education, whether at the level of the individual or of the society (Harris \& Jarrett, 1990). Maglen (1990) also argued that that this micro-level evidence has been fragmentary and inconclusive; however, he accepts the proposition that in the agricultural sector, levels of education can have a direct and measurable impact on productivity.

A further group of studies plays down the role of education as a crucial ingredient for economic development, thereby focusing on the more indirect role played by education in the relationship. First, sociologists reinforced human capital theory by suggesting that education at all levels contributes to economic growth through imparting general attitudes and disciplines and specific skills necessary for a variety of workplaces, thus creating an overall flexible workforce that is able to adapt to new working environments (Adams, 2002; Asian Development Bank, 2001). Other arguments hold that education is likely to contribute to a change in people's beliefs, values, and behaviour that are conducive to development, thus transforming a traditional society into a modern one (Morris \& Sweeting, 1995). Individuals are also more likely to receive important tangible returns from their tertiary education: generally the higher the educational attainment, the higher the chance to be employed and the higher their wages. Hence the private returns from higher education do provide individuals with incentives to invest in education (Vincent-Lancrin, 2004). In this regard, the Task Force on Higher Education and Society (2000) stated that though higher education is able to improve individual lives, it also simultaneously enriches the wider society, thus creating a substantial overlap between private and public interest. In other words, the more educated the individual, the better chance there is for success in the labour market. At the same time, a more educated workforce will create a more dynamic and competitive economy. The change in incomes and educational levels has also given rise to social and demographic changes. For example, declining birth rates, better health, higher life expectancy, lower crime, and better governance are all conducive to economic growth and development (Adams, 2002; Asian Development Bank, 2001; World Bank, 2002).

Another aspect of the discussion of the indirect relationship between education and economic development has focused on the role of the university and its functions. Universities and their academic staffs play a key role in society by teaching and training, conducting research, and most importantly, providing a source of ideas that are vital for the enrichment of the nation (Altbach, 1998; Lim, 1983). The ability to conduct research and 
generate new ideas will, in turn, drive innovation and new technology, all of which are essential as today's economies are profoundly shaped by the technological revolution (Altbach, 1998; Selvaratnam, 1993; United Nations Development Programme, 1997). What clearly emerges from this brief analysis of the role of education in economic development is that there are many theories that offer differing explanations of the relationship between education and various economic indicators. The dominant theory has been human capital theory. Other theories have yielded key insights; however, they are not entirely conclusive. However, despite the difficulties involved in unravelling the complexities that are embedded within the relationship, it remains possible to state that education has played various roles in the modernisation and economic development of different societies. What is also important to grasp is that the impact of education on economic, social, and political development is increasingly not to be confined within the borders of the nation-state. With respect to examining the outcomes of international education, in particular, we are already seeing evidence that these are being played out on a global stage.

\section{RESEARCH ON GRADUATE OUTCOMES TO DATE}

Some work has been done on the outcomes of Australian-educated international graduates; however, much of it is now very dated. In 1969, D. M. Keats published a tracer study that reports findings from research with more than 500 Australian educated Asian Colombo Plan fellows and trainees. Her focus was to determine their employability post graduation, the applicability of their training, and the perceived value of their education by colleagues and associates. Based on a questionnaire answered by more than 500 returnees from Southeast Asia and a structured interview of nearly 200 people, she found that, on the whole, Australian education had brought positive benefits to recipients and was viewed favourably by their colleagues. Problems encountered by graduates on their return home were mainly concerned with recognition of the Australian qualification and the relevance of their training for the recipient's home country. Respondents in the Keats study frequently reported little opportunity to use their education and training in their work "back in Asia," pointing to a mismatch between the education provided in Australia and local conditions (Keats, 1969).

Possibly the most ambitious study to date is the tracer study by Daroesman and Daroesman, Degrees of Success: A Tracer Study of Australian Government Sponsored Indonesian Fellowships, 1970-1989 (1992). This work is now 15 years old, and the time that 
has passed since it was undertaken has seen not only unprecedented growth in international education in Australia but also significant changes in regional and global politics, and cultural and economic development levels. This study, like other more recent works (Nilan, 2005), looked specifically at the outcomes of Indonesian graduates. Again, the overall feeling of respondents was that many advantages accrued from their Australian study. For example, many government sector workers reported promotions and pay rises because of their overseas training. Increased income also occurred for as many as $80 \%$ of the respondents because they were receiving outside work on top of their primary job in which they received additional payments. In terms of productivity, almost all respondents stated that their Australian experience had changed their views and practices; however, the majority of them could not clearly define the ways in which views and practices had changed. Some suggested that their improved English-speaking abilities gave rise to more "self-confidence."

Negative responses reported in the study were found in respect to career development where many respondents stated that their career directions were overly dependent on local or national departmental policies and bureaucratic control rather than on their individual qualifications or expertise. Other respondents complained of frustration based on the relevance of their overseas training to their current positions. A small group of respondents reported that, on their return to their former place of employment after graduation, nothing had changed for them in terms of increased responsibility, or greater scope in which to use their new knowledge and skills. For these graduates, it was as if the Australian education experience had not occurred. For a number of graduates, this sense of the irrelevance or futility of their Australian study was exacerbated by the lack of ongoing contact with the university at which they had studied after their return home. Like Keats's study, the work by Daroesman and Daroesman has some historical depth, eliciting responses from returning graduates up to 18 years after their Australian educational experience.

Other less extensive studies have also indicated recurring themes such as strong hierarchical and bureaucratic control back home that impedes the career development of the overseas graduate, inadequate economic rewards, and the lack of relevance of the Australian education especially when compared with students with domestic qualifications (Chur-Hansen, 2004; Curtis \& Lu, 2004; Weisblat, 1993). Despite the many significant 
disadvantages faced by the overseas-educated student on returning home, Cannon (2000) suggested that the benefits reported by graduates, mainly in terms of attitude, confidence, respect, and recognition received have rendered their overseas education worthwhile. In his study, he concluded that the outcomes of international education have led to the new phenomenon called the third place. Students who return home have become more complex members of their own society as their reintegration into their home country requires them to integrate the experiences, values, and knowledge gained from their overseas study with the experience of being and working at home. Other researchers have also referred to this phenomenon as the third culture, a term deployed to account for the space occupied by those who bridge the gaps between traditional cultures and the West (Hodgkin, 1966). Cannon's work $(1999,2000)$ focuses on the experiences of Indonesian students on returning home after studying in Australia. Nilan's work $(2002,2005)$ also focuses on Indonesian AusAID students'experiences; and her findings raise serious questions about the "viability" (Nilan, 2005) of the AusAID scholarship program particularly when balanced against the fact that these funds directed toward support and development of higher education institutions in Indonesia, rather than the support of individual scholars completing degrees in Australia, might produce more tangible public and community benefits in the Indonesian context.

AusAID has undertaken some tracer studies of the outcomes of graduates from fellowship and scholarship programs; however, these reports are not in the public domain. Although we are constrained in reporting on these, it can be noted that they are limited in their foci to individual country programs and generally only capture responses from graduates up to 24 months postgraduation. Arguably the "education-as-aid" context in which AusAID operates may generate questions about graduate outcomes that have different emphases from the kinds of questions that may be asked in the new global tertiary education environment where international students are, in the majority of cases, funding their own education in Australian universities. As recognised by the ANAO in 1999, these questions pertain to the outcomes of education in relation to capacity building and overall labour market and human capital development in the graduates' home countries and, hence, require measures of the education of individuals as a public good in a development context.

We must concur with the ANAO (1999) that the kinds of measures of capacity building required to provide an accurate assessment of the educational efficacy of the 
Australian education and training provided to AusAID fellows and measures of the appropriateness of the ADS, and its predecessors, as a form of aid for development, are sorely lacking. This, we contend is an issue for educators and those in the aid and development arena. Without quality data on graduate outcomes over time, AusAID has little evidence on which to base policy, as in the profound debate in the "education-for-aid" sector over the relative benefits for development of directing aid funding to basic education as distinct from tertiary education; or to counter criticism of the ADS scheme as primarily benefiting the Australian universities that educate the AusAID fellows, at the expense of higher education infrastructure development in the countries to which AusAID directs such scholarship support (Guthrie, 2002; Nilan, 2005; Task Force on Higher Education and Society, 2000).

There is also other data that we need, which conforms to a wider sense of graduate outcomes than currently operates but goes to the heart of the sorts of claims made by educators themselves (Bigelow, 1998; Bullen, Kenway, \& Robb, 2004) and others (Task Force on Higher Education and Society, 2000) concerning the ethical, cultural, and attitudinal development enabled by tertiary education. Thus, beyond important data on the appropriateness of the skills and knowledge acquired by graduates for the situation in their home countries is a range of questions relating to cultural shifts, and changes in values and attitudes prompted through the Australian study experience. For these, at present, no measures exist. To gain accurate measures of the educational outcomes, the World Bank (2004b) advocates the use of "baseline" research in the form of either surveys or interviews administered with scholarship recipients at a point before their international education experience commences to gather data on baseline skills and knowledge. With this data in hand, research into graduate outcomes will have certain key reference points from which to measure "impact" and "outcomes" of the educational experience more accurately. We suggest that such baseline measures could, if instituted, readily extend to cover cultural and attitudinal dimensions as well. The collection of such baseline data, of course, presupposes the existence of mechanisms for broad-based, qualitative outcomes research. Again, in the Australian international education context, no such mechanisms as yet exist.

The analysis of the limited research available suggests that, in general, international higher education graduates report advantages in career development and personal development. However, all studies report significant reservations about the appropriateness 
of the Australian education to local conditions in the recipient's home country. Issues such as inadequate economic rewards, lack of relevance of the overseas training, and readjustment difficulties must be addressed adequately to optimise the benefits received by international students from their Australian education. Despite these difficulties, because some societies recognize the significant status of an overseas education (Lewis, 1992), and because for some groups access to university education in their home countries is limited, international students will continue to seek higher education within the Australia education sector.

\section{RESEARCH OUTSIDE THE AUSTRALIAN CONTEXT}

Beyond the Australian context, major philanthropic and nongovernment providers of scholarship assistance, such as the World Bank (2004a, 2004b), have also conducted studies of the outcomes of graduates funded through their programs. These reports also adopt the tracer study methodology and, as such, are somewhat limited in scope; that is, they tend to restrict themselves to seeking data on outcomes from graduates within 2 years of graduation. Arguably, the time frames adopted also work to limit the conceptualisation and measures of "outcomes" deployed in these studies. One function of this perspective is that much of the data gathered by Australian researchers and those working in other contexts deal with the graduates' immediate postgraduation reflections on the study experience itself and the transition back to employment in the home country, with a significant proportion of data generated around what may be described as operational issues-ease of transition to the new study environment, support services for international students, logistical concerns such as timeliness of stipend payments, and receipt of transcripts and documentation on completion of studies. Where studies are sponsored by bodies granting and/or administering awards, such as AusAID or the World Bank, these concerns are to be expected; however, this kind of data adds little to our knowledge of the value of the education and training received by such graduates.

\section{RETHINKING WHAT IS MEANT BY OUTCOMES}

Within the literature on graduate outcomes-whether local, international, or in the "education-as-aid for development" contexts-outcomes tend to be seen only in terms of the first labour market destination of the graduate on completion of study; or in the case of 
many returning international students, their career progression on returning to their former place of employment. The approach to graduate outcomes to date has been limited to outcome indicators such as starting salary, field of employment, and in the case of the tracer studies of international graduates, data on position in organisation and attempts to measure the "multiplier" effects of education, such as numbers of employees being supervised and/or trained by the graduate. Most commonly, such tracer studies, such as those produced by the World Bank (2004b), limit their inquiry to graduates 20 to 24 months out; thus they provide no data on the capacities enabled in the midcareer or mature professional. It is generally acknowledged in the international literature on the outcomes of international education, including the graduate education of those from developing countries, that more research is needed by way of developing measures of outcomes across a range of fields, and which will go some way to answering important questions about the relative value for capacity building of technical, professional, and applied education as distinct from generalist and liberal education, and of coursework education as distinct from graduate research (Task Force on Higher Education and Society, 2000; World Bank, 2004b).

With respect to developing a wider conception of "outcomes" than economic returns from the education, or the impact of university education on the careers of individual graduates, the literature is replete with assertions about the wider cultural and social benefits of education, with some authors pointing to the influence of such cultural factors on development (Adams, 2002; Asian Development Bank, 2001; Morris \& Sweeting, 1995), on entrepreneurship, and on facilitating the growth of robust democratic civil society (World Bank, 2002). Again, data that points to how this might occur is lacking. This, of course, is a familiar problem and one that scholars and others advocating the "value" of areas of study that are not directly vocational or directly tied to areas of explicit economic value, in particular, have grappled with over time (Bigelow, 1998, p. 37; Bullen et al., 2004). Thus, though development indices invariably point to correlations between levels of education in any society and economic activity (Task Force on Higher Education and Society, 2000; World Bank, 2002), the processes by which educated people affect their societies, across a range of domains, is as yet little understood.

\section{PROSPECTUS FOR RESEARCH NEEDED INTO THE MEDIUM- TO LONG-TERM OUTCOMES OF AUSTRALIAN-EDUCATED INTERNATIONAL GRADUATES}


Thus, we argue, in the first instance, there has simply not been enough research into the outcomes of Australian-educated international students given the length of time this sector has been delivering international education and the scale and scope of internationalisation of the sector now. Second, we contend that such research as has been done is now is dated. Third, we contend that there are limitations with the literature on the outcomes of international education within the Australian context and beyond. The primary problem we have identified is the narrow time frame of most research to date that is restricted to examining graduate outcomes within 2 years of the international graduates' completion of study. Partly as a function of this but also driven by other factors, namely the difficulties inherent in the task of developing a methodology for relating the individual benefits of education to the public sphere, is the limited conception of, and hence measures for, outcomes of education that have been deployed.

As a way of addressing this significant gap in our knowledge, we advocate research that will investigate and analyse the outcomes for international students of Australian universities over the "education-as-aid" era and into the current situation in which international students are funded from a variety of sources. The preliminary stage of this work, a pilot study by us on the careers of distinguished Monash Malaysian alumni since the 1960s, shows that these largely Colombo Plan graduates (Australia Malaysia Cultural Foundation, 2001) value the experience of studying in Australia and continue to value it over time, primarily as one that broadened their minds and gave them a sense of how mature middle-class-based civil society operated, at a stage that their own society had not yet reached on the trajectory of industrialisation and rapid economic growth. Data gathered from these graduates, who are now mature and senior professionals in a range of fields, have enabled us to begin developing a far wider and more inclusive definition of "outcomes" than those currently deployed in the literature. For example, alumni have been asked to give details of their professional, business, cultural, and other activities across a wide range of domains, and we have assembled data on activities that include the following:

- identification and tracking, and measurement of academic impact of education (particularly of PhD dissertations and master's theses) by means of tracing publications arising from research, career paths in university administration; 
- measurement of impact in the professions by tracking leadership in professional associations, consultancies to the government, participation by professionals in education through adjunct/honorary positions in higher education institutions;

- tracking of participation in cultural institutions and industries;

- tracking of participation in religious and similar organisations;

- public profiling, role as "public intellectual," contributions as journalist/commentator, community leadership;

- tracking of career paths of senior bureaucrats;

- tracking patents registered by graduates;

- identifying innovative companies established by graduates;

- identifying their creation and leadership of nongovernmental organizations in the locality and region;

- tracking of gradates' representation in national politics and in international/regional bodies;

- representation in international regulatory bodies on behalf of their country, for example, United Nations, International Labour Organisation (ILO), World Bank, World Trade Organisation (WTO), Association of South East Asian Nations (ASEAN), and so on;

- other transnational activities and involvement;

- identifying graduates' contribution to technical innovation in public facilities and infrastructure, health care, education systems, environmental management.

In addition to these areas of inquiry, our interviews with alumni also deal explicitly with areas of culture (and interculturalism), with attitudes and ethics. In the absence of the "baseline" data advocated by the World Bank, participants are asked to describe or reconstruct their dominant values and attitudes at the point before embarking on study in Australia, and to give their perceptions of the changes that they experienced (or in some cases, resisted).

Data from participants in Malaysia on their professional, cultural, and community activities over several decades provides a far richer measure of the outcomes of the Australian education experience than has been available to date. From it a picture of multilayered, rich, and complex processes of transformation, which centrally involve integrating the Australian educational experience with the experience of returning home, is beginning to emerge. Assessing the outcomes of Australian education in the context of a career in business, hospital administration, politics, or the academy that spans nearly 30 years begins to give embodiment to claims that, "the norms, values, ethics and knowledge that tertiary education can impart to students contribute to the social capital necessary to construct healthy civil societies and socially cohesive cultures, as well as to achieve good governance and democratic political systems" (World Bank, 2002, p. 5). Malaysia, whose 
association with Australian higher education dates back to the Colombo Plan, is now a rapidly developing economy, with a growing middle class. In 2006-2007, we repeated the study with Australian-educated graduates in Fiji and plan to continue the work in Vietnam. Fiji, which has also had a long association with Australian higher education, is at quite a different stage in economic and industrial development and grappling with a set of particular issues in managing an ethnically diverse community. Vietnam, also with a rapidly growing economy, has, as yet, a relatively new relationship with Australian higher education. It is hoped that the cultural, economic, and political differences between these three countries and their differing relationship to Australia and Australian higher education will strengthen our study with respect to its focus on the outcomes of Australian international education.

\section{CONCLUSION}

In late 2005, it was widely anticipated that the Australian Prime Minister Mr. John Howard would use his participation in the inaugural meeting of the East Asia Summit in Kuala Lumpur as the occasion to announce the revival of the Colombo Plan (Walters, 2005) through a scheme that will refocus educational aid on higher education and redress the trend in Australian education aid away from support for international fellows studying in Australian universities in favour of support for technical, vocational, and basic education. The Colombo Plan \#2 scholarship scheme that emerged is the Endeavour Scheme, which includes the Endeavour Leadership Awards (DEST, 2006a). The scholarship scheme, particularly the leadership awards that are aimed at people with "the potential to assume leadership roles" in their countries and from these roles "influence social and economic policy in the Asia and Pacific region" (Department of Education, Science and Training [DEST], 2006b), is based on assumptions of the kinds of links between higher education and capacity building, and higher education and the development of civil society that have been the subject of this article and concerning that, we have argued, very little sustained research has been done.

The Endeavour Leadership Awardees will certainly take up places in an Australian higher education system that is radically different from the one that Colombo Plan fellows entered during the decades between 1950 and 1980. Initiated by the early Colombo Plan experiences and the rapid internationalisation that has occurred in the past two decades, 
Australian universities now know much more about the supports required by international students to ensure that their Australian educational experience is productive, enjoyable, and rewarding and have, as Grant Harman (2005) demonstrated, a significant body of good research on almost every aspect of the international student experience to help shape policy, practice, and pedagogy.

However, some things have changed very little since 1950. Beyond a few limited studies, and many axioms, anecdotes, and assertions, we still know very little about the value, relevance, and outcomes of international graduates' Australian education over time. Surely such research, as much as research on the international students' Australian study experience, is needed to ensure that Australian universities are providing education of quality and relevance to the thousands of students from all over the world now studying within Australian institutions.

\section{REFERENCES}

Adams, D. K. (2002). Education and national development: Priorities, policies, and planning. Hong Kong: Asian Development Bank and University of Hong Kong, Comparative Education Research Centre.

Altbach, P. G. (1998). Comparative higher education: Knowledge, the university, and development. Hong Kong: Comparative Education Research Centre.

Altbach, P. G. (2000, May-August). Why higher education is not a global commodity. Association of African Universities (AAU) Newsletter, 7(2), 5-6.

Asian Development Bank. (2001). Education and national development in Asia: Trends, issues, policies, and strategies. Manila, Philippines: Author.

Auletta, A. (2000). A retrospective view of the Colombo Plan: Government policy, departmental administration and overseas students. Journal of Higher Education Policy and Management, 22(1), 47-59.

AusAID. (1999a). Snapshot of training-March 1999. Retrieved August 3, 2005, from http://www.ausaid.gov.au/about/stats/pdfs/snapshot399.pdf

AusAID. (1999b). Snapshot of training-September 1999. Retrieved August 3, 2005, from http://www.ausaid.gov.au/about/stats/pdfs/snapshot999.pdf

AusAID. (2000). Snapshot of training-As of 31 March 2000. Retrieved August 3, 2005, from http://www.ausaid.gov.au/about/stats/pdfs/snapshot300.pdf 
AusAID. (2001). Snapshot of training-As of 31 March 2001. Retrieved August 3, 2005, from http://www.ausaid.gov.au/about/stats/pdfs/snapshot301.pdf

AusAID. (2003). AusAID annual report 2002-2003. Retrieved October 13, 2005, from http://www.ausaid.gov.au/anrep03/pdf/anrep02_03.pdf

Australian Education International, Department of Education, Science and Training. (2006). International student enrolments in Australia-1994 to 2006. Retrieved February 27, 2007, from

http://aei.dest.gov.au/AEl/MIP/Statistics/StudentEnrolmentAndVisaStatistics/2006/ 2006_TimeSeriesGraph_pdf

Australian Malaysia Cultural Foundation. (2001). The Colombo Plan for cooperative economic development in South and South East Asia 1951-2001: The MalaysianAustralian perspective. Canberra, Australia: Author.

Australian National Audit Office. (1999). Management of the Australian development scholarship scheme. Retrieved August 3, 2005, from http://www.anao.gov.au/WebSite.nsf/Publications/4A256AE90015F69B4A25690000 $18 \mathrm{BC} 60$

Back, K., Davis, D., \& Olsen, A. (1996). Internationalisation of higher education: Goals and strategies. Canberra: Australian Government Publishing Service.

Bigelow, J. (1998). Valuing humanities research. In Australian Academy of the Humanities (Eds.), Knowing ourselves and others: The humanities in Australia into the 21st Century: Vol. 3. Reflective essays (pp. 37-58). Canberra: Commonwealth of Australia.

Bullen, E., Kenway, J., \& Robb, S. (2004). Can the arts and humanities survive the knowledge economy? A beginner's guide to the issues. In J. Kenway, E. Bullen, \& S. Robb (Eds.), Innovation and tradition: The arts, humanities and the knowledge economy (pp. 1022). New York: Peter Lang.

Cannon, R. (1999). International education and a professional edge for Indonesian graduates: The third place? In D. Davis \& A. Olsen (Eds.), International education: The professional edge: A set of research papers presented at the 13th Australian International Education Conference, Fremantle 1999 (pp. 15-36). Deakin: IDP Education Australia.

Cannon, R. (2000). The outcomes of an international education for Indonesian graduates: The third place? Higher Education Research and Development, 19(3), 357-379. 
Chur-Hansen, A. (2004). Returning home to work: Malaysian students who studied medicine overseas. Medical Teacher, 26(4), 343-348.

Curtis, S., \& Lu, W. (2004). The impact of western education on future Chinese Asian managers. Retrieved August 3, 2005, from http://www.cheshire.mmu.ac.uk/bms/home/research/pdf-doc/doc-07.pdf Daroesman, I. P., \& Daroesman, R. (1992). Degrees of success: A tracer study of Australian government sponsored Indonesian fellowships 1970-1989. Canberra: Australian International Development Assistance Bureau and the International Development Program of Australian Universities and Colleges (IDP).

Department of Education, Science and Training. (2006a). Australian scholarships. Retrieved March 14, 2007, from http://www.australianscholarships.gov.au

Department of Education, Science and Training. (2006b). Endeavour awards. Retrieved March 14, 2007, from http://endeavour.dest.gov.au

Department of Foreign Affairs and Trade. (2005). Education without borders: International trade in education. Canberra: Australian Education International.

Gairing, W. (2001). The role of a national agency. In D. Richardson (Ed.), International alumni relations (pp. 25-32). Amsterdam: European Association for International Education.

Guthrie, G. (2002). Crumbs from the table: The impact of globalisation and internationalisation on the poverty of Third World universities. In P. Ninnes \& L. Tamatea (Eds.), Internationalizing education in the Asia-Pacific region: Critical reflections, critical times (pp. 325-338). Armidale, Australia: University of New England, School of Education.

Harman, G. (2005). Internationalisation of Australian higher education: A critical review of literature and research. In P. Ninnes \& M. Hellstén (Eds.), Internationalising higher education: Critical explorations of pedagogy and practice (pp. 119-140). Hong Kong: University of Hong Kong, Comparative Education Research Centre.

Harris, G. T., \& Jarrett, F. G. (1990). Educating overseas students in Australia: Who benefits? Sydney, Australia: Allen \& Unwin.

Hodgkin, M. C. (1966). Australian training and Asian living. Perth: University of Western Australia Press.

Hodgkin, M. C. (1972). The innovators: The role of foreign trained persons in Southeast Asia. Sydney, Australia: Sydney University Press. 
Jackson, R. G. (1984). Report of the committee to review the Australian overseas aid programme. Canberra: Australian Government Publishing Service.

Keats, D. M. (1969). Back in Asia-A follow-up study of Australian-trained Asian students. Canberra: Australian National University, Department of Economics Research School of Pacific Studies.

Lewis, P. (1992). Singapore students in Australia: What's a degree worth? Murdoch, Australia: Murdoch University Economics Programme.

Lim, C.-Y. (1983). Education and national development. Singapore: Federal Publications.

Lowe, D., \& Oakman, D. (Eds.). (2004). Australia and the Colombo Plan, 1949-1957

(Documents on Australian Foreign Policy). Canberra, Australia: Department of Foreign Affairs and Trade.

Maglen, L. R. (1990). Challenging the human capital orthodoxy: The education-productivity link re-examined [Electronic version]. Economic Record, 66(195), 281-294.

Morris, P., \& Sweeting, A. (Eds.). (1995). Education and development in East Asia. New York: Garland.

Nerad, M., \& Cerny, J. (1999). From rumours to facts: Career outcomes of English PhDs: Results from the PhDs ten years later study [Special issue]. Communicator, 32(7). Retrieved August 3, 2005, from http://www.grad.washington.edu/envision/PDF/TenYearsLater.pdf

Nilan, P. (2002). Impacts of aid scholarship-funded study in Australian universities: The case of Indonesia. In P. Ninnes \& L. Tamatea (Eds.), Internationalizing education in the Asia-Pacific region: Critical reflections, critical times (pp. 423-437). Armidale, Australia: University of New England, School of Education.

Nilan, P. (2005). The viability aid scholarship-funded study in Australia: The case of Indonesia. In P. Ninnes \& M. Hellstén (Eds.), Internationalising higher education: Critical explorations of pedagogy and practice (pp. 159-180). Hong Kong: University of Hong Kong, Comparative Education Research Centre.

Oakman, D. (2004). Facing Asia: A history of the Colombo Plan. Canberra, Australia: Pandanus Book.

Selvaratnam,V. (1993). Meeting the human resource needs of developing countries: The contribution of overseas education. In C. D. Goodwin (Ed.), International investment 
in human capital: Overseas education for development (pp. 63-77). New York: Institute of International Education.

Shamsul Huq, M. (1965). Education and development strategy in South and South East Asia. Honolulu, HI: East-West Venter Press.

Smart, D., \& Ang, G. (1993). Exporting education: From aid to trade to internationalization? IPA Review, 46(1), 31-33.

Smart, D., \& Ang, G. (1996). The internationalisation of Australian higher education. International Higher Education, 6, 4-5.

Tapingkae, A. (Ed.). (1976). Higher education and economic growth in Southeast Asia. Singapore: Regional Institute of Higher Education and Development.

Task Force on Higher Education and Society. (2000). Higher education in developing countries: Peril and promise.Washington, DC:World Bank.

Trembath, R. (for the Australian Research Council and Graduate Careers Council of Australia). (1999). Career paths for PhD graduates: A scoping study. Canberra: Australian Research Council and Graduate Careers Council of Australia.

United Nations Development Programme. (1997). Human development report 1997. New York: Oxford University Press.

Vincent-Lancrin, J. (2004, October 11-12). Building capacity through cross-border tertiary education. Paper presented for the UNESCO/OECD Australia Forum on Trade in Educational Services, Bridging the Divide-Building Capacity for Post-Secondary Education Through Cross-Border Provision, Sydney, Australia. Retrieved August 3, 2005, from http://www.oecd.org/dataoecd/43/25/33784331.pdf

Visser, L. (2001). Utrecht University's international alumni programme. In D. Richardson (Ed.), International alumni relations (pp. 15-23). Amsterdam: European Association for International Education.

Walters, P. (2005, December 12). Howard woos top Asian students. The Australian. Retrieved August 3, 2005, from http://www.theaustralian.news.com.au

Weisblat, A. M. (1993). Evaluation of overseas fellowship programs. In C. D. Goodwin (Ed.), International investment in human capital: Overseas education for development (pp. 179-188). New York: Institute of International Education.

World Bank. (2002). Constructing knowledge societies: New challenges for tertiary education. Retrieved September 15, 2005, from 
http://www1.worldbank.org/education/PDF/Constructing\%20Knowledge\%20Societi es.pdf

World Bank. (2004a). The Joint Japan/World Bank Graduate Scholarship Program: A capacity building initiative for developing countries-2004 annual report. Retrieved August 3, 2005, from http://siteresources.worldbank.org/INTWBISFP/Resources/5514911101331203556/Japan_AR2005.pdf

World Bank. (2004b). Joint Japan/World Bank Graduate Scholarship Program (JJ/WBGSP) Tracer Study VI. Retrieved October 5, 2005, from http://siteresources.worldbank.org/INTWBISFP/Resources/5514911108589837615/tracer_studies6.pdf

\section{ABOUT THE AUTHORS}

Denise Cuthbert is currently an associate dean (Graduate Research) and a deputy dean in the Faculty of Arts, Monash University. She has more than 20 years' experience in teaching, research, and university administration and has a strong record in higher degree by research supervision, including the successful supervision of several AusAID candidates. She is currently engaged in a mapping exercise of labour market outcomes of higher degrees by research (i.e., master's by research and $\mathrm{PhD}$ ) graduates in the humanities and social sciences.

Wendy Smith is a senior lecturer in management in the Faculty of Business and Economics, Monash University and director of the Centre for Malaysian Studies, Monash Asia Institute. An anthropologist by training, she has extensive experience in qualitative social science methodology. She is currently conducting research on the career outcomes of Monash Malaysian alumni since the 1960s.

Janice Boey holds a bachelor's of commerce and a master's in diplomacy and trade. She is currently working on the Distinguished Malaysian Alumni Project. 